\title{
A Sociolinguistic Study of Muslim and Christian Wedding Invitation Genre in the Jordanian Society
}

\author{
Murad Hassan Mohammed Sawalmeh \\ University of Huddersfield, United Kingdom \\ E-mail: msawalmeh@yahoo.com
}

Doctoral Candidate in Linguistics, Department of English Language and Linguistics

\begin{abstract}
The present study reports an investigation of the generic structure of Muslim and Christian wedding invitation genre in the Jordanian society. It is a sociolinguistic study. The researcher believes that many aspects of these invitation cards such as organizational structure, content and so forth, may provide a lot of information about the social dimensions of those who tend to hold a wedding ceremony. The data were elicited through a questionnaire that consists of twenty-five items compiled from invitation cards for both Muslims and Christians. The findings of the study show that the organizational structure of the invitation cards in Islam and Christianity in the Jordanian society is systematic and influenced by social, economic, and religious factors. Finally, this study recommends that further research to be conducted investigating other invitation cards for other events in the Jordanian society such as invitation cards for attending meetings, birthday parties, lectures, celebrations, royal feasts, tribal reconciliation, etc.
\end{abstract}

Keywords: wedding invitations; genre; socio-cultural factors; Christian; Muslim; wedding ceremony

\section{Council for Innovative Research}

Peer Review Research Publishing System

Journal: Journal of Advances in Linguistics

Vol.5, No.1
editorjalonline@gmail.com

www.cirjal.com 


\section{INTRODUCTION}

A wedding invitation card (henceforth often WIC) is defined as a letter asking the recipients (the couple's relatives, friends, colleagues, and neighbors, etc) to attend a wedding ceremony. It is typically written in formal language and sent out to the recipients about one to two weeks before the finalized wedding date. So, once the wedding dates are planned by the couple, the next important step is deciding upon the WIC. A WIC needs to have all the necessary information that a guest needs about the wedding celebration. The most important information is the names of the bride and groom, the time and date of the ceremony and the venue of the ceremony. Raheja and Puri (1995, p. 68) state that the WIC can be organized in a number of formats. However, the following important information must be included: (1) the fact that it is a wedding event; (2) the names of the hosts; (3) the names of the bride and the groom; (4) data and the year of the ceremony; (5) the time; (6) and address of the ceremony. There is no doubt that choosing the right wedding invitation for guests is not an easy task. With all of the different styles and designs that are available for wedding invitations in Jordan, it makes the choice much more difficult for the bride and the groom to decide upon the suitable WIC. According to Alora (2012), every WIC "differs from person to person according to the customs and culture". So, the couple tend to be very careful when they choose the appropriate WIC. That is, they tend to go through hundreds of different wedding invitation cards, sort out the ones they don't like, and then choose from the ones that caught their attention.

The communicative purpose of a WIC is to inform people that a wedding party is going to be held in a specific time and place and to invite or call upon them to participate in this occasion by their presence. A wedding party is a significant event in the Islamic Jordanian society. It functions as an announcement to the public that $X$ and $Y$ are a husband and wife from now on.

In order to identify and understand the special characteristics of written wedding invitations in the Jordanian society, we are supposed to consider them in their "native context in terms of the social norms and conventions that give rise to such occasions" (Momani and Al-Refaei 2010, p. 62). Moreover, understanding the nature and manifestations of the wedding invitation cards in Arabic as used and practiced by the Jordanian society, we need to understand the socio-cultural context related to the social norms and values of the occasion studied (Al-Ali 2006, p. 693).

A wedding can be defined as a union between a man and a woman to create a new family and to share their sexual, economic, and emotional lives (Kim, as cited in Park, 1997). For Hill (2011), the term wedding refers to "a day when two individuals embark on a life-long journey of togetherness".

Lee et al. (2001, p. 32) state that each "country and culture has different traditions and various forms of festivals". In the Jordanian society, wedding ceremonies are characterized by peculiar customs and traditions. They usually start with meetings between the bride, groom, and their mothers. They usually meet in a public place or in the bride's house, and get to know each other. Then, there is a tradition called Jaha, where the bride's family and relatives host a reception in their house. Following this, the groom's curator formally asks for the bride's hand from her father or the eldest man in her family. After the bride's curator agrees, the families read the Fatiha (the first Sura in the Holy Qur'an). Next comes the marriage contract (Katb el-Kitab), when the couple exchange vows at the bride's house in the presence of a religious official (Sheikh or Ma'thoun) and two witnesses signing their names to the marriage contract. Marriage contract, as Gurthrie (2001, p. 15) puts is, included detailed "inventories and gifts to the bride from her own family, as well as the dowry (mahr), which is for her sole use and benefit"

The Muslim wedding rituals in Jordan have two celebrations: an engagement party (khutbah) and a wedding party (zafaf). In the engagement party, the groom places the ring on the bride's right middle finger, while the bride places the ring on the groom's right middle finger. The wedding party, on the other hand, is a larger affair. On the wedding day, the bride wears a white dress, while the groom wears a formal suit, often black in color. Then the couple's family along with the invitees go in a procession of cars (fardeh) to a special wedding hall or a large hotel to celebrate the wedding.

Next, the bride and groom switch rings from their right hand to the left one. With this ritual, the wedding begins. The bride and groom have the first dance, after that the wedding guests join in by singing and dancing with the newly-wed couple. Shoup (2003, p. 95) points out that the songs that were traditionally sung by the female guests told of the strength of the groom and praised the beauty of the bride, cultural ideals of a proper young couple. In this context it is worth mentioning that in some strict Jordanian weddings, men may not dance with women inside the hall. So only the female guests and children enter the wedding hall together with the couple. Next comes the cutting of the wedding cake by the couple. After the guests have finished eating the cake, the wedding ceremony is over.

As far as the Christian wedding is concerned, it "reflects lot of divinity or God's covenant in many customs and traditions" (Singhal, 2011). The traditional Christian wedding rituals mainly consist of an engagement party. After this, there is the informal hen party known as the Bridal shower. All the females gather at the bride's place and rejoice by singing and dancing. They shower gifts on the bride and she offers them a pink cake with a hidden thimble. Whoever gets the piece with the thimble, is supposed to get married next.

On the wedding day, the groom sends a car to pick up the bride and waits for her outside the church. After she arrives, the Best man of the groom welcomes her with a bouquet of flowers. Then the couple walk down the corridor gracefully to reach the altar. There the priest awaits them and offers them best wishes. He then reads psalms from the Hoy Bible, which is followed by sermon called Homily on the sacredness of the wedding. Following this, he asks question to the bride and the groom regarding their consent for the marriage.

The couple make promises to stay with each other through thick and thin and exchange rings. These rings are blessed by the priest first, to instill love and faith between the two couple. After this, the couple are blessed by the gathering and the 
priest. The wedding concludes by signing on a register and the couple walk down the aisle, arm in arm. A copy of the signed page is later sent to the Registrar of Marriages.

The Christian wedding is followed by a reception, which is a celebration party. It is a grand affair, wherein the couple are welcomed by the guest, with a shower of confetti. After this, the newly-wed couple cut the wedding cake and feeds each other. The Toastmaster then offers a toast in the honor of the couple. Besides, the Reception party is celebrated with dance and dinner party. After the guests have finished having their dinner, the wedding is finished.

Although there have been some international studies that have already conducted on wedding invitation genre (e.g., Al-Ali, 2006; Momani and Al-Refaei 2010), there still exists a dearth of research carried out on Arabic wedding invitation genre. Therefore, the present study would contribute to deal with this Arabic "homely" genre in order to fill in this lacuna in knowledge.

The purpose of the study reported here is to examine the generic structure of Arabic invitation wedding genre in the Jordanian society. More specifically, the present study attempts to address the following research questions:

1- What are the distinctive features that form the organizational structure of the Muslim and Christian wedding invitation genre in Jordan?

2- To what extent do the social, cultural and religious factors have any influence on the production and textual organization of such genre?

3- What are the similarities and differences between Muslim and Christian wedding invitation cards?

This study is significant because, as the research literature has shown, it is the first attempt, as far as I am aware, to analyze and investigate the genre of Muslim and Christian wedding invitations in Jordan. Furthermore, this study sheds some light on the similarities and differences between wedding invitation genre in Islam and Christianity in the Jordanian society. Moreover, the significance of this study lies in its contribution towards providing much more detailed information for those who would like to engage in the social practices and events in the Jordanian society. Further, I hope the results of this study will be of great benefit in understanding the generic constructions of what Miller (1984) calls "homely" discourse as well as in understanding the social, religious and cultural factors that influence this communicative event.

\section{LITERATURE REVIEW}

There has been increased interest in the study of wedding invitation genre in recent years. Clynes and Henry (2005), for example, analyzed to what extent Bruneian students in a tertiary level were able to identify the genre components of Malay Wedding Invitations in Brunei as well as the lexico-grammatical features. To achieve this purpose, two groups of analyses were carried out - one by the authors, and one by nine undergraduate students taking the genre analysis course as part of their BA study at the University of Brunei Darussalam. For the authors' analysis, a corpus of 20 wedding invitations was analyzed in terms of the discourse community, the communicative purposes, the move structure: obligatory and optional moves, and the salient lexico-grammatical and non-linguistic features.

As for the students' analysis, they were given an assignment to identify the obligatory and optional moves as well as the possible order of these moves, and explain why certain key linguistic features appear in the wedding invitation genre in terms of the communicative purpose of the genre. Then, the authors' and students' analyses were compared. The results of the study showed that the students were able to accurately identify the obligatory and optional moves and their order; however, they were less successful at explaining the surface linguistic features in terms of the overall communicative purposes of the wedding invitation genre.

Al-Ali (2006), in his article entitled" Religious affiliations and masculine power in Jordanian wedding invitation genre", examined a total of 200 Arabic written wedding invitations in terms of their typical discourse generic component patterns and the role of the socio-cultural norms and values in forming this genre. He found that religious affiliation and masculine kinship authority played an important role in constructing the text component selection and colouring the lexical choices and naming practices.

Al-Refaei (2010) analyzed a sample of 55 wedding invitation cards to explore the generic structure of Jordanian wedding invitations and examine the socio-cultural factors that shape the content of such wedding invitations. After analysis, she found that Jordanian wedding invitations do not have a fixed certain form. She also stated that not all moves are used in every wedding invitation in Jordan, so not all moves are obligatory but there are some optional moves as well. She found that there are some variations in the move orders of Jordanian wedding genre. She also found that the language of wedding invitations is affected by socio-cultural aspects. For example, the language of the Jordanian wedding invitation is characterized by religious features.

Al-Refaei and Momani (2010), using model of analysis proposed by Holmes (1997) and a modified version of the model outlined by Clynes and Henry, examined the generic structure of wedding invitations in Jordanian society in order to find out what components people employ to articulate the communicative purpose of these invitations. They also investigated the effect of socio-cultural aspects on the generic structure of wedding invitations. The study findings indicated that the wedding invitation genre in Jordan was built around obligatory and optional moves which communicate a lot of information about the socio-cultural values and norms in Jordanian society that affect the structure of such genre.

In conclusion, this study differs from all the above studies since it investigates the generic organizational structure of Muslim and Christian wedding invitation genre in the Jordanian society. Unlike other studies which focused on the 
discourse generic component patterns that people employ to articulate the communicative purpose of wedding invitations, the present study focuses mainly on the social, cultural and religious factors that influence the production of such genre. Furthermore, this study could be considered new because it throws some light on the similarities and differences between wedding invitation genre in Islam and Christianity in the Jordanian society.

\section{3- METHODOLOGY}

\subsection{Population of the Study}

The population of this study consisted of all people (males and females) living in the city of Jerash, some 45 kilometers north of Amman, the capital of Jordan. Those people were from two religions: Islam and Christianity. This population will help in showing the potential organizational structure of wedding invitations within the Jordanian society with reference to their religions.

\subsection{Sample of the Study}

The sample included in this study consists of 235 males and 190 females. To select the participants of the present study, a simple random sampling method was used because it is regarded as one of the most reliable methods to obtain a representative sample. The participants, selected for the purpose of this study, are between 22 and 65 years of age. None of them were illiterate. Very few of the respondents had only elementary education, while some of them had secondary education. As for higher education level, some of the respondents had diplomas, some had bachelor's degrees, others had master's degrees, whereas few of them had doctoral degrees in different fields. Tables 1 and 2 demonstrate the distribution of the study sample according to religion, sex, number and education.

Table 1. Shows the distribution of the sample according to religion, sex, and number:

\begin{tabular}{|l|c|c|}
\hline Religion & Number of males & Number of females \\
\hline Islam & 136 & 106 \\
\hline Christianity & 99 & 84 \\
\hline Total & 235 & 190 \\
\hline
\end{tabular}

Table 2. Shows distribution of the sample according to their education:

\begin{tabular}{|l|c|c|}
\hline Education & Number of males & Number of females \\
\hline Elementary & 66 & 39 \\
\hline Secondary & 76 & 27 \\
\hline Diploma degree & 25 & 21 \\
\hline Bachelor's degree & 52 & 8 \\
\hline Master's degrees & 11 & 0 \\
\hline Doctoral degrees & 5 & 190 \\
\hline Total & 235 & 35 \\
\hline
\end{tabular}

\subsection{Data Elicitation}

The data were elicited through a questionnaire. This questionnaire consists of two parts. The first part included five questions that elicit demographic information about the subjects, i.e., sex, age, place of living (the city of Jerash) in addition to religion and educational levels. Religion is regarded as one of the most important variables in this study. These five questions investigate whether sex, age, place of living, religion and educational levels have affects on the structure of the wedding invitation genre.

The second part consisted of twenty five items investigating the generic organization of wedding invitation cards for both Muslims and Christians. After careful observation of the available wedding invitation cards, the researcher has written the twenty five items that were used to collect the data. The questionnaire items consisted of two types (Multiple-choice and Yes/No questions). The questionnaire was personally distributed by the researcher to the respondents. All the subjects were asked to answer the questions of the questionnaire with the assistance of the researcher.

\section{3- RESULTS AND DISCUSSIONS}

The main focus of this study was to analyze the Muslim and Christian wedding invitation cards within the Jordanian society. In order to achieve this objective, the researcher used a questionnaire as a tool to collect data that would show 
any potential and significant similarities and differences between the wedding cards of Muslims and Christians in this regard. The results of this tool will be presented in detail below.

The analysis of the questionnaire results approximately showed some significant differences between Islam and Christianity. Results of question one which is about the person who offers the WIC showed that $57.6 \%$ of Muslims' wedding invitation cards are offered by the father, $30.7 \%$ of them by the elder brother, $4 \%$ by the cousin, and $7.7 \%$ by others such as the bridegroom himself. As regards Christians, the analysis indicated that $75 \%$ of Christians' wedding invitation cards are offered by the father, $18.7 \%$ of them by the elder brother, and $6.3 \%$ of them by others. It is evident from the questionnaire results that the father is the one who often offers the wedding invitation cards for both Muslims and Christians (see table 1).

Table 1. The person who offers the wedding invitation card

\begin{tabular}{|l|c|c|c|c|c|}
\hline $\begin{array}{l}\text { Who offers the } \\
\text { invitation card? }\end{array}$ & Father & Elder brother & Cousin & Others & Total \\
\hline Muslims & $57.6 \%$ & $30.7 \%$ & $4 \%$ & $7.7 \%$ & $100 \%$ \\
\hline Christians & $75 \%$ & $18.7 \%$ & NA & $6.3 \%$ & $100 \%$ \\
\hline
\end{tabular}

A glance at table 2, which is about mentioning the name of the bride on the invitation card, revealed that $27 \%$ of Muslims mention the bride's name. More interestingly, it has been observed that all the Christians (100\%) mention the name of bride on their invitation cards. It is worth noting here that $73 \%$ of Muslims don't mention the bride's name because of either their social, religious or personal preferences. However, in recent years, it has been very common for the couple to mention the bride's name in the wedding invitation card, especially when these couple are well-educated and belong to high-class families.

Table 2. Mentioning the bride's name

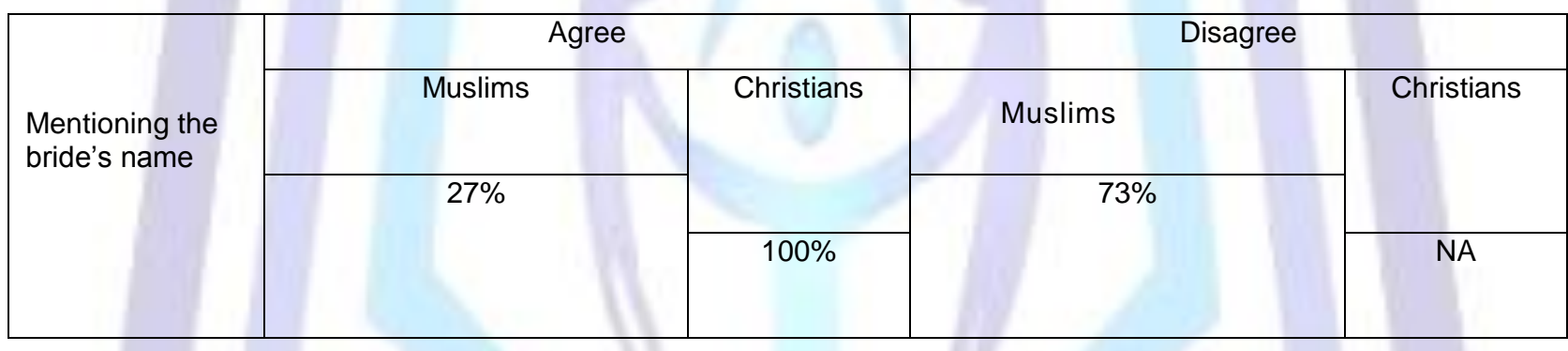

With regard of those who do not mention the name of the bride on the wedding card, it was found that $85 \%$ of Muslims use the honorific attribute "kari:matuh" (his honorable daughter) instead of the bride's name, $15 \%$ of them used the word: "ibnatuhu" (his daughter). As for Christians, they all mention the bride's name on the WIC. (see table 3).

Table 3. The way the bride's name is mentioned.

\begin{tabular}{|l|c|c|c|c|}
\hline $\begin{array}{l}\text { How is the bride's } \\
\text { name mentioned } \\
\text { instead? }\end{array}$ & $\begin{array}{c}\text { His honorable } \\
\text { daughter }\end{array}$ & His daughter & Others & Total \\
\hline Muslims & $85 \%$ & $15 \%$ & $0 \%$ & $100 \%$ \\
\hline Christians & NA & NA & NA & NA \\
\hline
\end{tabular}

An examination of table 4, which is about the reasons why the bride's name isn't mentioned in the invitation card, showed that $31.6 \%$ of Muslims don't mention the bride's name because of social contentment, $48.4 \%$ of them was because of religious contentment and $20 \%$ of them was due to personal contentment. Al-Ali $(2011$, p. 708$)$ asserts that the deletion of the bride's name from the wedding invitation indicates an inherent preference on the part of the groom and bride's families to avoid mentioning the names of the females in the invitations, either for religious or personal preferences. In case of Christians, there are no reasons for not mentioning the bride's name. 
Table 4. The reasons why the bride's name isn't mentioned in the invitation card

\begin{tabular}{|l|l|l|l|l|}
\hline $\begin{array}{l}\text { What are the reasons } \\
\text { for not mentioning the } \\
\text { bride's name? }\end{array}$ & $\begin{array}{l}\text { Social } \\
\text { Contentment }\end{array}$ & $\begin{array}{l}\text { Religious } \\
\text { Contentment }\end{array}$ & $\begin{array}{l}\text { Personal } \\
\text { Contentment }\end{array}$ & Total \\
\hline Muslims & $31.6 \%$ & $48.4 \%$ & $20 \%$ & $100 \%$ \\
\hline Christians & NA & NA & NA & NA \\
\hline
\end{tabular}

As for question five, that is about the one who insists on not mentioning the bride's name in the invitation card, findings showed that $14.3 \%$ of Muslims report that the decision is up to the groom's father to mention the bride's name or not, $7.1 \%$ report that it is to the bride's family, and $78.6 \%$ report that it is up to the groom's himself. In comparison with Muslims, Christians have no reasons for not mentioning the bride's name in the WIC (see table 5).

Table 5. The person who insists on not mentioning the bride's name in the invitation card

\begin{tabular}{|l|c|c|c|c|}
\hline $\begin{array}{l}\text { Who insists on not } \\
\text { mentioning the bride's } \\
\text { name? }\end{array}$ & Groom's father & Bride's family & Groom himself & Total \\
\hline Muslims & $14.3 \%$ & $7.1 \%$ & $78.6 \%$ & $100 \%$ \\
\hline Christians & NA & NA & N A & NA \\
\hline
\end{tabular}

Considering table 6, that is about mentioning the bride and groom's job title in the invitation card, it was found that $30.7 \%$ of Muslims mention the job title, while $69.2 \%$ refuse to mention it. As for Christians, $43.7 \%$ of them insist on mentioning their job titles and $56.3 \%$ don't. Clearly, it has been observed that the groom and the bride's name is preceded with an academic or professional title printed in large font and bold type such as "Doctor", "Engineer", "Pharmacist", "Judge" or "Lawyer". These titles reflect the couple's high level of education. Al-Khatib (2007) finds that "as a sign of prestige, Jordanian people are fond of using titles". It is worth mentioning here that making explicit reference to such professional or academic titles before the inviters' names exhibits a sense of self-promotion as these titles reflect their social status (Al-Ali 2006, p. 701).

Table 6. Mentioning the bride and groom's job title in the invitation card

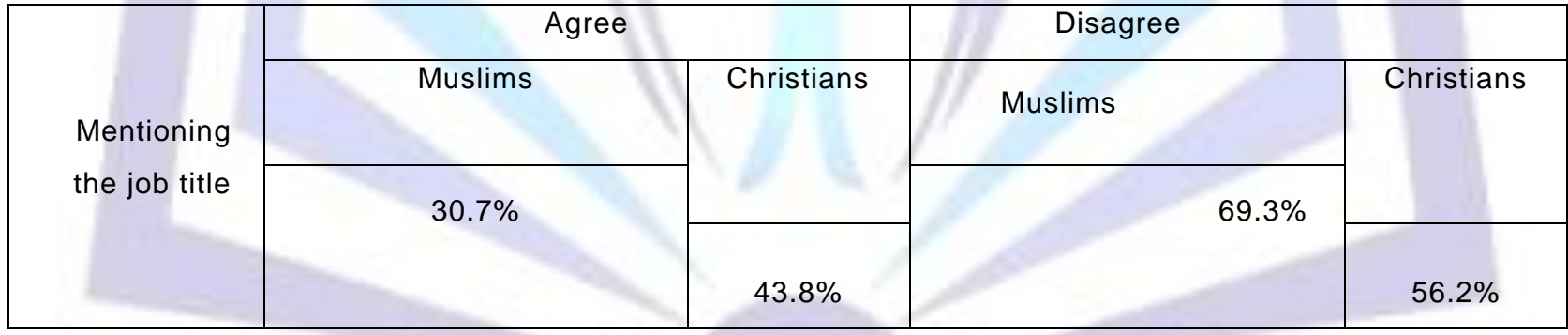

A glance at table 7, which is about beginning the WIC with a verse from the Holy Qur'an, demonstrates that $53.8 \%$ of Muslims usually begin their invitation cards with the following verse from the Holy Qur'an:

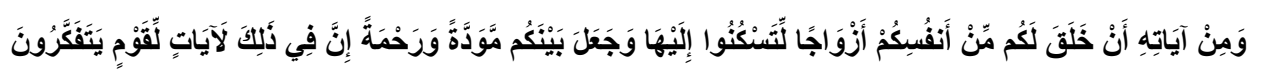

\section{wa min aya:tihi Pan xalaqa lakum min anfusikum Pazwa:dzan litaskunu: Pilayha: wadzaৎala baynakum mawadatan wa-raћmah. Pina fi: ठa:lika laPa:ya:tin liqawmin yatafakkaru:n}

(And of his signs is this: he created for you helpmeets from yourselves that ye might find rest in them, and he ordained between you love and mercy. Lo, herein indeed are portents for folk who reflect).

Surah Al-Rum, verse 21

It is very evident that most Muslim wedding invitation cards carry some verses of the Holy Qur'an. Davidson (2001) points out that using Quranic verses is meant to "bestow blessings on the bride and groom for the journey ahead of them". Furthermore, using some verses of the Holy Qur'an is seen as a sign of adherence to Islamic religion, thus, resulting in solidarity among the members in the Muslim community in Jordan (Momani and Al-Refaei 2010, p. 67). 
It is worth noting that the Muslims, who don't use the verse from the Holy Qur'an, tend to use a verse of poetry such as:

أفراحنا طابت وفاحَ عَبيرها فجذور ها تُروى بسنةِ احمد

haya toyu:r alxair zaǵridi fawq aldziba:h Palmopmina:ti waǵrridi

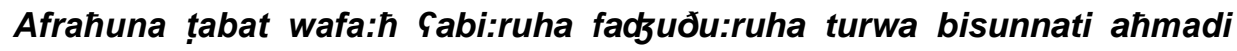

It is worth mentioning that poetic verses are a fantastic way to personalize a wedding invitation. Moreover, including some meaningful verses in the invitation cards is a unique way to make the wedding event memorable in a true sense because these verses convey the couple's pleasure and feelings about their marriage. Couples often use famous verses from a song or part of their favorite poems to express happiness and to rejoice the wedding occasion.

With the importance of poetry in wedding invitation genre, it would be significant now to note that the poetry texts, composed by the couple themselves, are beautifully inscribed at the heart of the WIC to bless the wedding occasion and express the romantic feelings and emotions for the best occasion of the couple's lives.

Table 7. Beginning the invitation card with a Quranic Verse

\begin{tabular}{|c|c|c|c|c|}
\hline \multirow{4}{*}{$\begin{array}{l}\text { Beginning the } \\
\text { invitation card with } \\
\text { averse of the Holy } \\
\text { Qur'an. }\end{array}$} & \multicolumn{2}{|c|}{ Agree } & \multicolumn{2}{|c|}{ Disagree } \\
\hline & Muslims & \multirow[t]{2}{*}{ Christians } & & \multirow[t]{2}{*}{ Christians } \\
\hline & \multirow{2}{*}{$53.8 \%$} & & \multirow{2}{*}{$46.2 \%$} & \\
\hline & & NA & & NA \\
\hline
\end{tabular}

Having a look at table 8, which investigated if the WIC begins with a text of the Bible, results of the subjects' answers revealed that $100 \%$ of Christians use the following common text of the Bible:

1- "bilmadzdi walkara:mah kalillhuma"

بالمجد والكرامة كللهما

(Marry them with glory and dignity)

2- "ma dzamaSahu Alla:h la yufariquhu insa:n" ما جمعة الله لا يفرقه إنسان

(What Allah combines cannot be separated by humans)

3- "wlikai yaSlamu Pna ismuki qad dukir Gala haða Palbeit Palaðe banait"

$$
\text { ولكي يعلموا أن اسمك قد ذكر على هذا البيت الذي بنيت }
$$

(To know that your name had been mentioned upon this house you built)

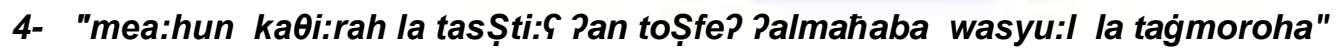

$$
\text { مياه كثيرة لا تستطيع أن تطفئ المحبة والسيول لا تغمرها }
$$

(Much water couldn't put out love and flood can't overwhelm it) 
Table 8. Beginning the invitation card with a text of the Bible

\begin{tabular}{|c|c|c|c|c|}
\hline \multirow{6}{*}{$\begin{array}{l}\text { Beginning the } \\
\text { invitation } \\
\text { card with } \\
\text { a text from } \\
\text { the } \\
\text { bible }\end{array}$} & \multicolumn{2}{|c|}{ Agree } & \multicolumn{2}{|c|}{ Disagree } \\
\hline & Muslims & \multirow[t]{2}{*}{ Christians } & Muclims & \multirow[t]{2}{*}{ Christians } \\
\hline & \multirow[t]{4}{*}{$\overline{N A}$} & & \multirow{4}{*}{ NA } & \\
\hline & & & & \\
\hline & & $100 \%$ & & NA \\
\hline & & $100 \%$ & & $T N A$ \\
\hline
\end{tabular}

A careful examination of table 9 , which is about including the WIC poetic verses, showed that $7.7 \%$ of Muslims mention a verse of poetry, while $6.2 \%$ of Christians mention a verse of poetry such as:

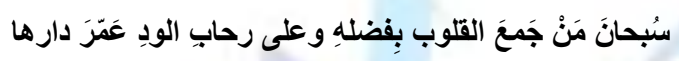

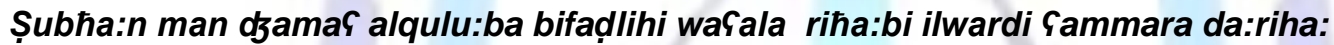

(Praise be to God whose generosity joined the hearts and Who established homes full of fondness.)

Table 9. Including the invitation card a verse of poetry

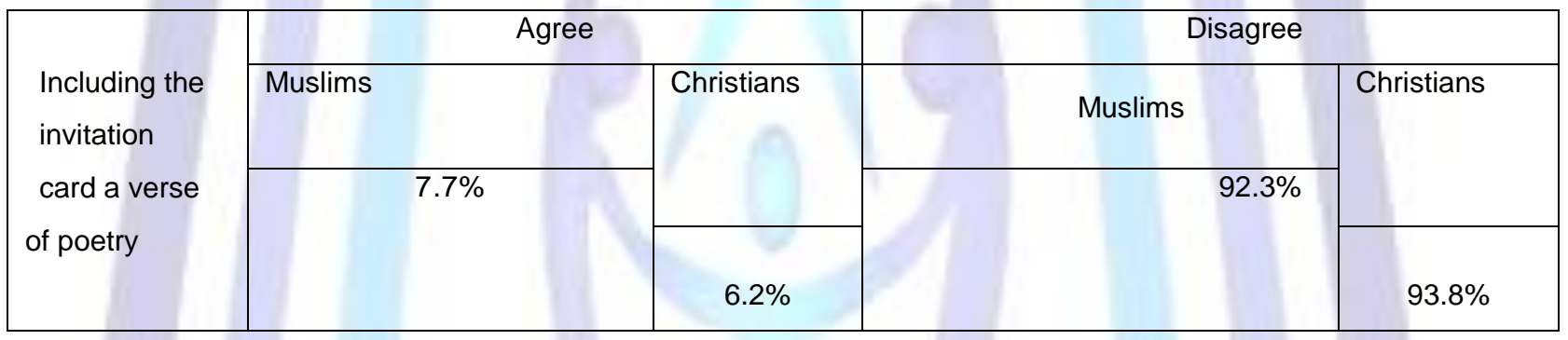

As for table 10, which is about if the WIC includes a statement to the invitees about not accompanying children, the results showed that $27 \%$ of Muslims mention a statement, while $18.8 \%$ of Christians mention a statement. During my interview with the subjects, I have found that Christianity urges the family to accompany their children to the wedding ceremony.

Table 10. Including the invitation card a statement to the invitees about not accompanying children.

\begin{tabular}{|l|l|l|l|c|}
\hline \multirow{2}{*}{$\begin{array}{l}\text { A statement to } \\
\text { the invitees about } \\
\text { not accompanying }\end{array}$} & Muslims & Christians & Muslims & Christians \\
\cline { 2 - 2 } children & $27 \%$ & & $73 \%$ & \\
\cline { 2 - 2 } & & $18.8 \%$ & & $81.2 \%$ \\
\hline
\end{tabular}

A glance at table 11, which investigated the statement that is used by those who don't like children to come to the wedding ceremony, showed that $37.1 \%$ of Muslims use the following direct statement:

$$
\text { يمنع اصطحاب الأطفال منعاً باتاً بأمر من إدارة الصلة }
$$

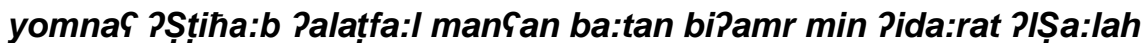

(The wedding hall does not permit accompanying children at all)

As shown in the table down, $14.2 \%$ of Muslims use the following indirect statement which is more polite than previous one:

$$
\text { جنة الأطفال بيوتهم }
$$

dzanna:t P/Pațfa:I biyu:tuhum 


\section{(Children's paradise is their house)}

It is clear that, $28.7 \%$ of Muslims use the following indirect statement:

\section{nawman hani:Pan lapța:likum نوما هنيئا لأولادكم \\ (Pleasant sleeping for your children.)}

As the table shows $20 \%$ of Muslims use the following indirect statement as well:

\section{Paћla:m saYi:dah liPatfa:likum أحلام سعيدة لأطفالكم \\ (Happy dreams for your children.)}

In contrast with Muslims, Christians prefer to accompany their children to the wedding ceremony. So, their wedding invitations do not include any notes asking for not bringing children to the wedding party.

Table 11. Statements used by people who don't want children to come to the wedding.

\begin{tabular}{|l|c|c|c|c|c|}
\hline $\begin{array}{l}\text { What is the } \\
\text { statement used by } \\
\text { people who }\end{array}$ & \multicolumn{1}{|c|}{$\begin{array}{c}\text { Not } \\
\text { don't want } \\
\text { children to come } \\
\text { to the wedding? }\end{array}$} & $\begin{array}{c}\text { Children's } \\
\text { paradise is } \\
\text { their homes } \\
\text { children }\end{array}$ & $\begin{array}{c}\text { Pleasant } \\
\text { sleeping } \\
\text { for your } \\
\text { children }\end{array}$ & $\begin{array}{c}\text { Happy } \\
\text { dreams } \\
\text { for your } \\
\text { children }\end{array}$ & Total \\
\hline Muslims & $37.1 \%$ & $14.2 \%$ & $28.7 \%$ & $20 \%$ & $100 \%$ \\
\hline Christians & NA & NA & NA & NA & NA \\
\hline
\end{tabular}

As for table 12, which is about if the WIC contains a statement to the invitees about not shooting, the results showed that $53.8 \%$ of Muslims and $25 \%$ of Christians mention the following statement:

\section{Plradza:P Gadam Pțla:q alৎyara:t Pana:riyah niha:Piyan}

(Please kindly no shooting at all)

$$
\text { الرجاء عدم إطلاق العيارات النارية نهائيا }
$$

Table 12. A statement to the invitees about not shooting

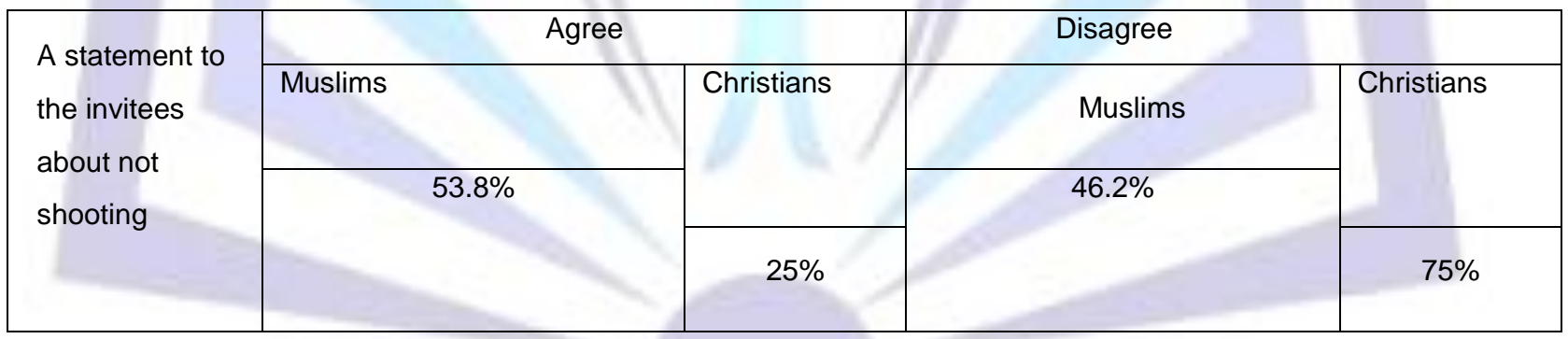

In regard to table 1 , that is about the price of the invitation card, analysis showed that the price of the WIC of $57.6 \%$ of Muslims and $50 \%$ of Christians is less than one Jordanian dinar. Whereas the price of the WIC of $38.4 \%$ of Muslims and $31.2 \%$ of Christians is less than half dinar. With relation to the rest of the subjects, the price of their WIC is more than one Jordanian dinar. 
Table 13. The price of the subjects' invitation cards

\begin{tabular}{|l|l|c|c|c|}
\hline $\begin{array}{l}\text { What is the price } \\
\text { of the invitation } \\
\text { card? }\end{array}$ & $\begin{array}{c}\text { Less than one } \\
\text { Jordanian dinar }\end{array}$ & $\begin{array}{c}\text { Less than half } \\
\text { Jordanian dinar }\end{array}$ & $\begin{array}{c}\text { More than one } \\
\text { Jordanian dinar }\end{array}$ & Total \\
\hline Muslims & $57.6 \%$ & $38.4 \%$ & $4 \%$ & $100 \%$ \\
\hline Christians & $50 \%$ & $31.2 \%$ & $18.8 \%$ & $100 \%$ \\
\hline
\end{tabular}

A careful examination of table 14, which is about how the WIC is formed, showed that forming the WIC of $27 \%$ of Muslims, and $25 \%$ of Christians is decided by the bride's family and the bridegroom's family. Whereas $34.6 \%$ of Muslims and $68.7 \%$ of Christians is decided by the bride and the bridegroom. In contrast, forming the WIC of $38.4 \%$ of and $6.3 \%$ of Christians is decided by the bridegroom himself.

Table 14. Forming the invitation card

\begin{tabular}{|l|c|c|c|c|}
\hline $\begin{array}{l}\text { How is the } \\
\text { invitation card } \\
\text { formed? }\end{array}$ & $\begin{array}{l}\text { Consultation } \\
\text { between the bride's } \\
\text { family and the } \\
\text { bridegroom's } \\
\text { family. }\end{array}$ & $\begin{array}{l}\text { Consultation } \\
\text { between the } \\
\text { bride and the } \\
\text { bridegroom. }\end{array}$ & $\begin{array}{l}\text { The } \\
\text { bridegroom } \\
\text { only. }\end{array}$ & Total \\
\hline Muslims & $27 \%$ & $34.6 \%$ & $38.4 \%$ & $100 \%$ \\
\hline Christians & $25 \%$ & $68.7 \%$ & $6.3 \%$ & $100 \%$ \\
\hline
\end{tabular}

With regards to table 15, which is about Putting the WIC in an envelope, it was found that $80 \%$ Muslims and $75.8 \%$ of Christians put their invitation cards in an envelope. The rest offer the invitation cards without envelopes.

Table 15. Putting the invitation card in an envelope

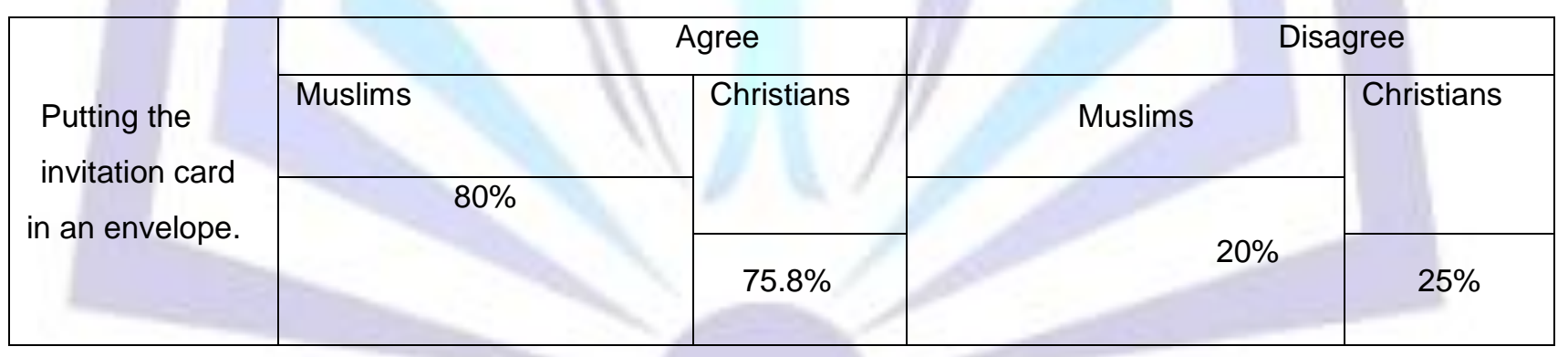

A closer look at table 16, which is about if the WIC is written in a language other than Arabic, it was found that most of the WIC are written in Arabic, whereas very few of them are written in English.

Table 16. Writing the invitation card in a language other than Arabic

\begin{tabular}{|c|c|c|c|c|}
\hline \multirow{4}{*}{$\begin{array}{l}\text { Writing the } \\
\text { invitation card in } \\
\text { a language other } \\
\text { than Arabic }\end{array}$} & \multicolumn{2}{|c|}{ Agree } & \multicolumn{2}{|c|}{ Disagree } \\
\hline & Muslims & \multirow[t]{2}{*}{ Christians } & Muslims & \multirow[t]{2}{*}{ Christians } \\
\hline & \multirow{2}{*}{$\mathrm{NA}$} & & \multirow[t]{2}{*}{$100 \%$} & \\
\hline & & $6.2 \%$ & & $93.8 \%$ \\
\hline
\end{tabular}

A glance at table 17, which is about the way in which the WIC is sent, it was found that $100 \%$ of Muslims and $75 \%$ of Christians send their invitation cards by hand. Only $6.3 \%$ of Christians send their invitation cards by fax. 
Table 17. The way in which the invitation card was sent

\begin{tabular}{|l|c|c|c|c|}
\hline $\begin{array}{l}\text { How is the } \\
\text { invitation card } \\
\text { sent? }\end{array}$ & By mail & By hand & By fax & Total \\
\hline Muslims & N A & $100 \%$ & N A & $100 \%$ \\
\hline Christians & $18.7 \%$ & $75 \%$ & $6.3 \%$ & $100 \%$ \\
\hline
\end{tabular}

An examination of table 18, which is about if the name of the publishing house is mentioned in the WIC, it was found that $88.4 \%$ of Muslims, and $50 \%$ of Christians mention the name of the publishing house in the WIC.

Table 18. Mentioning the name of the publishing house in the invitation card

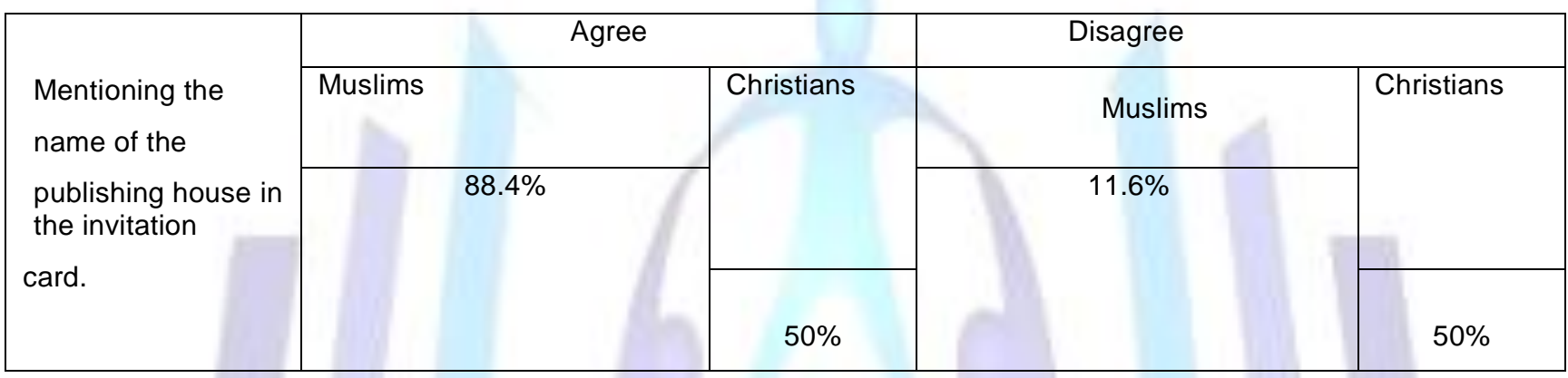

As for question nineteen which investigated where the name of the publishing house appears in the invitation card, it was found that the name of the publishing house of $95.4 \%$ of Muslims and $100 \%$ of Christians appear inside the invitation card, while only $4.6 \%$ of Muslims appear on the back of the WIC (see table 19).

Table 19. The place where the name of the publishing house appeared

\begin{tabular}{|c|c|c|c|}
\hline $\begin{array}{l}\text { Where does the name of the } \\
\text { publishing house appear? }\end{array}$ & $\begin{array}{c}\text { Inside the invitation } \\
\text { card }\end{array}$ & $\begin{array}{c}\text { Back of the } \\
\text { invitation card }\end{array}$ & Total \\
\hline Muslims & $95.4 \%$ & $4.6 \%$ & $100 \%$ \\
\hline Christians & $100 \%$ & NA & $100 \%$ \\
\hline
\end{tabular}

A look at table 20 , which is about if the WIC finishes with a statement of wishing happiness to the invitees, showed that $80.7 \%$ of Muslims and $93.8 \%$ of Christians finish their invitation cards with the following statement of wishing happiness to the invitees.

\section{da:mat PalPafra: $\hbar$ hali:fatu diya:rikum Palৎa:mirah}

(May happiness last and surround your prosperous homes)

\section{دامت الأفراح حليفة دياركم العامرة}


Table 20. Finishing the invitation card with a statement of wishing happiness to the invitees

\begin{tabular}{|c|c|c|c|c|}
\hline \multirow{5}{*}{$\begin{array}{l}\text { Finishing the } \\
\text { invitation card } \\
\text { with a statement of } \\
\text { wishing happiness } \\
\text { to the invitees }\end{array}$} & \multicolumn{2}{|c|}{ Agree } & \multicolumn{2}{|l|}{ Disagree } \\
\hline & Muslims & \multirow[t]{3}{*}{ Christians } & Mulim & Christians \\
\hline & \multirow{3}{*}{$80.7 \%$} & & \multirow{3}{*}{$19.3 \%$} & \\
\hline & & & & \\
\hline & & $93.8 \%$ & & $6.2 \%$ \\
\hline
\end{tabular}

As for table 21 , which is about if the WIC contains the place address of the event in the invitation card, revealed that all of the subjects mention where the wedding ceremony is held in the WIC.

Table 21. Mentioning the place address of the event in the invitation card

\begin{tabular}{|c|c|c|c|c|}
\hline \multirow{4}{*}{$\begin{array}{l}\text { Mentioning the } \\
\text { place address of } \\
\text { the event in the } \\
\text { invitation card }\end{array}$} & \multicolumn{2}{|c|}{ Agree } & \multicolumn{2}{|c|}{ Disagree } \\
\hline & Muslims & Christians & Muslims & Christians \\
\hline & $100 \%$ & & NA & \\
\hline & & $100 \%$ & & NA \\
\hline
\end{tabular}

In regard to table 22, which is about if the WIC contain information about the men party, results showed that $92.3 \%$ of Muslims and $68 \%$ of Christians mention information about the men's party. The rest of subjects don't.

Table 22. Mentioning information about the men party

\begin{tabular}{|l|l|l|l|c|}
\hline \multirow{2}{*}{$\begin{array}{l}\text { Mentioning } \\
\text { information }\end{array}$} & \multicolumn{2}{|c|}{ Agree } & \multicolumn{2}{c|}{ Disagree } \\
\cline { 2 - 4 } $\begin{array}{l}\text { about the } \\
\text { men's party }\end{array}$ & Muslims & & Muslims & Christians \\
\cline { 2 - 5 } & & & $7.7 \%$ & \\
\cline { 2 - 5 } & & $68.7 \%$ & & $31.3 \%$ \\
\hline
\end{tabular}

Considering table 23, which investigated if the WIC includes the time of the event, analysis of results showed that all of the subjects mention the time when the wedding ceremony is held (see table 23).

Table 23. Mentioning the time of the event in the invitation card

\begin{tabular}{|c|c|c|c|c|}
\hline \multirow{5}{*}{$\begin{array}{l}\text { Mentioning the } \\
\text { time of the event } \\
\text { in the invitation } \\
\text { card }\end{array}$} & \multicolumn{2}{|l|}{ Agree } & \multicolumn{2}{|c|}{ Disagree } \\
\hline & Muslims & \multirow[t]{2}{*}{ Christians } & Muslims & \multirow[t]{2}{*}{ Christians } \\
\hline & \multirow[t]{3}{*}{$100 \%$} & & \multirow[t]{3}{*}{ NA } & \\
\hline & & $100 \%$ & & \\
\hline & & & & $N A$ \\
\hline
\end{tabular}

Analysis of question twenty-four which is about the place in which the wedding ceremony is held showed that while $65.3 \%$ of Muslims hold their wedding ceremonies in hotels, the rest of them hold it at their homes. In contrast, all 
Christians hold it in churches. (see table 24).

Table 24. The place of the wedding ceremony

\begin{tabular}{|l|c|c|c|c|}
\hline $\begin{array}{l}\text { Where is the wedding ceremony } \\
\text { held? }\end{array}$ & Hotel & Church & $\begin{array}{c}\text { The bridegroom's } \\
\text { house }\end{array}$ & Total \\
\hline Muslims & $65.3 \%$ & NA & $34 . \% 7$ & $100 \%$ \\
\hline Christians & NA & $100 \%$ & NA & $100 \%$ \\
\hline
\end{tabular}

Finally, analysis of results of question twenty-five, the last question, which is about if the WIC contains a statement about having lunch, showed that $30.7 \%$ of Muslims and $43.7 \%$ of Christians mention a statement about having lunch in their invitation cards (see table 25).

Table 25. Mentioning a statement about having lunch

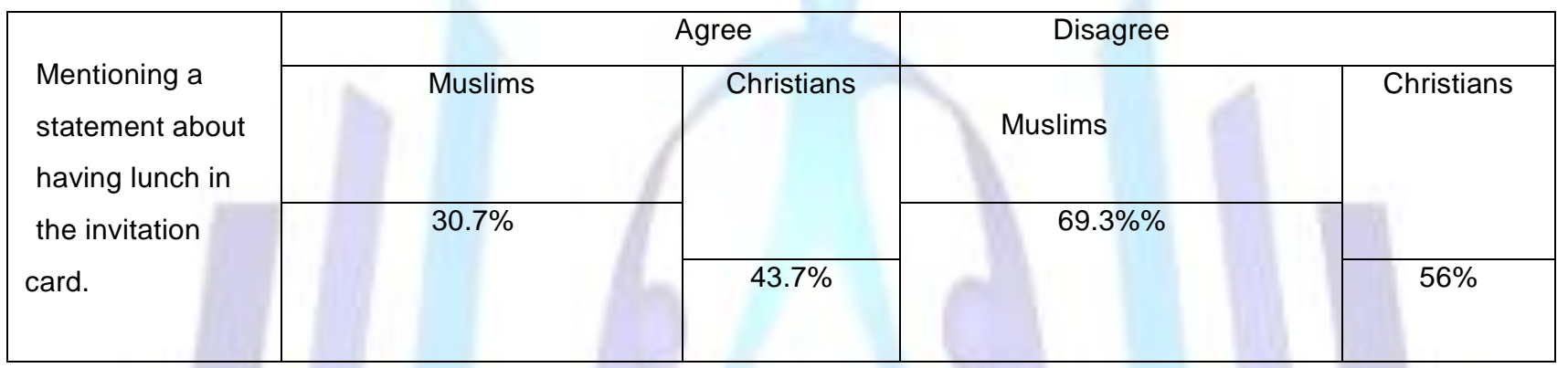

\section{IMPLICATIONS}

This study has shown that the main communicative function of wedding invitation cards is to invite people to attend wedding ceremonies. It has been observed through the analysis of the data that there are social, cultural and religious factors which affect the organization of invitation cards in the Jordanian society. The role of sex has proved to be an important factor especially in invitations for attending wedding parties. The name of the bride tends not to be mentioned when she belongs to a more socially conservative family. Thus, it is substituted by the formulaic word " kari:matuh " (his honorable daughter)) or the word "Jaqi:qatuh" (his sister). This is a tendency of the socially conservative Muslim families who do not like to announce the names of their daughters or sisters to the public. However, the name of the bride tends to be mentioned when she is well-educated and belongs to a less conservative family. In contrast with Muslim families, all of Christian families tend to mention the name of their daughters in the invitation cards.

The findings of this study reported here implied that the well educated people in Islam and Christianity tend to mention a plethora of professional and academic titles and qualifications before their names such as" Sheikh", "Doctor", "Engineer"," Lawyer", etc., in the invitation cards. It is worth mention that these titles are usually typed in bold-face with varying font sizes to indicate high level of education and high social status.

The discussion of the results of this study has shown that religious factors also seem to be of considerable importance. That is, Muslim and Christian societies have its faith in Allah deeply ingrained within its activities. These underlying Islamic and Christian values are reflected in the openings which utilize verses from the Holy Qur'an or texts from the Bible. For examples, Muslims usually begin their invitation cards with the following verse of Koran:

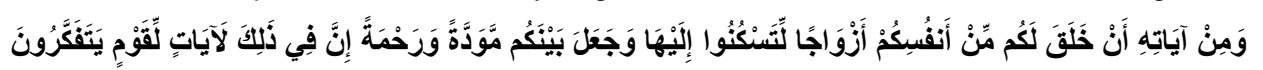

wa min aya:tihi Pan xalaqa lakum min anfusikum Pazwa:dzan litaskunu: Pilayha: wadzaSala baynakum mawadatan wa-raћmah. Pina fi: da:lika laPa:ya:tin liqawmin yatafakkaru:n

(And of his signs is this: he created for you helpmeets from yourselves that ye might find rest in them, and he ordained between you love and mercy. Lo, herein indeed are portents for folk who reflect).

Surah Al Rum, verse 21

While Christians begin their WIC with the following verses of the Bible:

\footnotetext{
"bilmadzdi walkara:mah kalillhuma"

بالمجد والكرامة كللهما

(Marry them with glory and dignity)
} 
"ma dzamaYahu Alla:h la: yufariquhu insa:n" ما جمعة الله لا يفرقه إنسان

(What Allah combines cannot be separated by humans)

$$
\text { ولكي يعلموا أن اسمك قد ذكر على هذا البيت الذي بنيت }
$$

"wlikai yaৎlamu Pna ismuki qad dukir Yala ha:ða Palbeit Palaði banait"

(To know that your name had been mentioned upon this house you built)

In addition, the analysis of the data indicated that the socio-economic status is also communicated in the invitation cards, and is found to be important in the description of the genre of invitation cards. This is revealed by the use of colorful and perfectly decorated invitation cards which include some drawings such as hearts, bunches of flowers, marriage rings or bouquets. Such invitation cards are expensive, and are meant to communicate other messages than inviting people to attend a wedding party; they tend to convey that the inviter enjoys a high economic status.

\section{CONCLUSION AND RECOMMENDATIONS}

The main focus of this study was analyzing the Muslim and Christian wedding invitation cards in the Jordanian society. In order to find out any potential significant similarities and differences between wedding invitation cards of Muslims and Christians, a questionnaire as a tool of collecting data was used. Data analysis revealed that there were significant differences in the way Muslims and Christians construct their wedding invitation cards.

The investigation of our data has shown that the communicative purpose of a text is the most important criterion for the identification of such wedding invitation cards. Dealing with various kinds of wedding invitation cards within the Jordanian Islamic and Christian societies revealed that social, cultural and religious factors are of great significance in the description of invitation genre.

The results of this study indicated that there were noticeable differences between wedding invitation cards of Muslims and Christians. For instance, Muslims usually tend not to mention the name of the bride in the invitation cards, while Christians does. What is more, Muslims tend to start their invitation cards with a verse of Quran or a verse of poetry, whereas Christians start them with a text of the Bible only. In addition, Muslims tend to hold their wedding ceremonies whether in a wedding hall or in the groom's house, while all Christians hold it in a church. Moreover, it can be said that form of invitation cards according to this study is systematic and affected by the social status, education, and religion.

Finally, three recommendations could be given in this study. First of all, it may be valuable to carry out research papers investigating other invitation cards for other events in the Jordanian society such as, invitation cards for attending meetings, lectures, celebrations, royal feasts and tribal reconciliation. Second, studies that investigate the generic structures of 'homely' discourse in Arabic such as obituaries, congratulations, greetings, apologies are very rare. Therefore, it is significant for future researchers to examine 'homely' discourses in order to fill this lacuna. Finally, it would be worthwhile to compare and contrast similar genres across different cultures to come up with their "universal or language specific tendencies," to use Swales' (1990) terminology (p. 64). For example, comparing Jordanian wedding invitation cards with British or American ones.

\section{ACKNOWLEDGMENT}

Firstly and above all, I would like to thank Allah Almighty who has given me strength, patience and endurance to meet the challenge of this research. Secondly, my most heartfelt appreciation goes out to my parents, sisters and brothers, whose love, constant support and encouragement cannot be measured. Last but never least, my deepest thanks go to my supportive and faithful wife for her understanding and for sharing my commitment to complete this interesting research.

\section{REFERENCES}

[1] Al-Ali, M. (2006). Religious Affiliations and Masculine Power in Jordanian Wedding Invitation Genre. Discourse \& Society,17 (6), 691-714.

[2] Al-Khatib, M. (1997). Congratulation and Thank-You Announcements in Jordanian Newspaper: Cultural and Communicative Functions. Language, Culture and Curriculum, 10 (2):156-70.

[3] Alora, S. (2012, August 16). Heartfelt Muslim Wedding Cards. [Online ]

Available:http://www.articlesbase.com/weddings-articles/heartfelt-muslim-wedding-cards-6126582.html

[4] Al-Rifa'i, D. (2006). Socio-textual practices in the genre of written wedding invitations in the Jordanian society. Unpublished M.A. thesis, Jordan University of Science and Technology.

[5] Clynes, A., \& Henry, A. (2004). Introducing Genre Analysis Using Brunei Malay Wedding Invitations. Language Awareness, 13 (4), 225-242. 
[6] Davidson, N. (2011, May 19). Muslim wedding cards. [Online ] Available:http://www.articlesbase.com/giftsarticles/muslim-wedding-cards-4789432.html

[7] Gurthrie, S. (2002). Arab women the middle ages: private lives and public roles. London: Westbourne Grove.

[8] Hill, O. (2011, November 11). Muslim Wedding Invitation. [Online ] Available:http://www.articlesbase.com/weddingsarticles/muslim-wedding-invitation-5386378.html

[9] Lee, T., Lee J., \& Chung, Y. (2011). A Comparative Study on Eastern and Western Wedding Ceremonies in Korean Films and Hollywood Films. World Academy of Science, Engineering and Technology 77: 32-41

[10] Miller, C., (1984). Genre as Social Action. Quarterly Journal of Speech, 70,151- 167

[11] Momani, K., \& Al-Refaei, D. (2010). A Socio -Textual Analysis of Written Wedding

Invitations in Jordanian Society. Language for special purposes, professional communication,

knowledge management and cognition, 1 (1), 61-80

[12] Park, C. (1997). Consumption in the Korean Wedding Ritual: Wedding Ritual Values, Consumer Needs, and Expenditures. Journal of Family and Economic Issues, 18 (2), 191-209

[13] Raheja, N. and Puri. (1995). How to arrange a wedding. New Delhi: Palus Press.

[14] Shoup. J. (2006). Culture and Customs of Jordan. London: Greenwood Press.

[15] Singhal, S. (2011). Christian Wedding - A Beautiful Ceremony. [Online ] Available: http://www.articlesbase.com/weddings-articles/christian-wedding-a-beautiful-ceremony-5154066.html

[16] Swales, J. M. (1990). Genre analysis: English in academic and research settings. Cambridge, MA: Cambridge University Press.

\section{Author Biography}

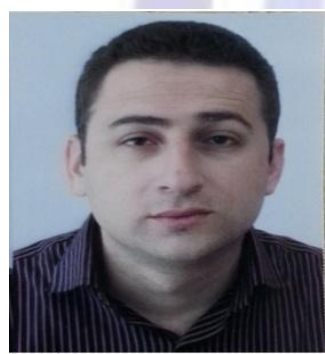

Murad Hassan Sawalmeh (born in Jordan, 1982) is currently a PhD candidate in Linguistics at the University of Huddersfield, United Kingdom. He obtained his M.A. degree in linguistics from the University of Jordan in 2007. He has over eleven years of experience teaching English as a second and foreign language in Jordan, the United Arab Emirates and Saudi Arabia. His main areas of interests lie in sociolinguistics, error analysis, translation and genre analysis in particular. 